\title{
Teaming ERP System Efficiently into an Academic State of Affairs
}

\author{
Subodh Kesharwani', Ramendu Roy ${ }^{2}$ and Ashish Agarwal ${ }^{3}$ \\ ${ }^{1}$ School of Management Studies, Indira Gandhi National Open University, New Delhi \\ 110068, India subodhkesharwani@gmail.com \\ ${ }^{2}$ Director, Motilal Nehru Institute of Research \& Business Administration, Allahabad \\ 211003, India ramendu_roy@rediffmail.com \\ ${ }^{3}$ School of Engineering and Technology, Indira Gandhi National Open University, New \\ Delhi 110068, India ashish_ka@yahoo.com
}

\begin{abstract}
The academic institution in the earth has been progressively shifting from ivory tower to economic engine. Economy in the world and an academic institution are witnessing a transitioning phase. Academia and Industry repeatedly re-establish their apparatus and mechanism with modern systems. On the other hand, scrapping legacy systems and replacing them with more contemporary software, which we in general called as Enterprise Resource Planning (ERP) System. The accountability of Academic State of Affairs specially an Open and Distance learning (ODL) system is consequently, exceptionally imperative in this paradigm. With the initiation of ERP System, which is a part of Information and Communication Technology (ICT), academia has augmented manifold. The specific objective of this paper is to study and expose how efficiently the pattern of availability and use of ERP System by the universities in the conventional \& contemporary mode around the world, accomplish their educational goals. The findings of this study will be constructive to distance mode universities as well as other conventional universities in the enrichment of the programme and also, in identifying ways and means of adapting methods to suit the local conditions. Overall endeavor of this paper is to take care of the institutions systems that are broaden across the globe, so to triumph over the artificial boundaries and thus to bind these two system (ERP and Academia) together to function in harmony.
\end{abstract}

Keywords: ERP System, Information Technology, Academic Integration, State-ofAffairs, Enterprise, Legacy system, Integrated system, SWOT Analysis, University system, Material requirement planning (MRP) manufacturing resource planning (MRP II), EDUSAT

\section{INTRODUCTION}

The basic tools for understanding the role of technology in competitive advantage are the ERP system [1]. The objectives of this paper are to initiate ERP systems and why these systems are significant to the operation of the businesses. The motive is to

Please use the following format when citing this chapter:

Kesharwani, S., Roy, R., Agarwal, A., 2007, in IFIP International Federation for Information Processing, Volume 255, Research and Practical Issues of Enterprise Information Systems II Volume 2, eds. L. Xu, Tjoa A., Chaudhry S. (Boston: Springer), pp. 1147-1157. 
understand the principles of function-oriented design, which is the most frequently used design strategy for current integrated systems. There are five foremost systems that shape the core of administrative information systems for most higher education institutions: financial, human resources, grants management, libraries, and student. The flexibility and enhanced software capabilities make available by these ERP systems permit the University to stay put competitive and compliant, and bring into line with the efficiency initiative. Well-built Contemporary software supports faculty and staff in fulfilling the University's undertaking.

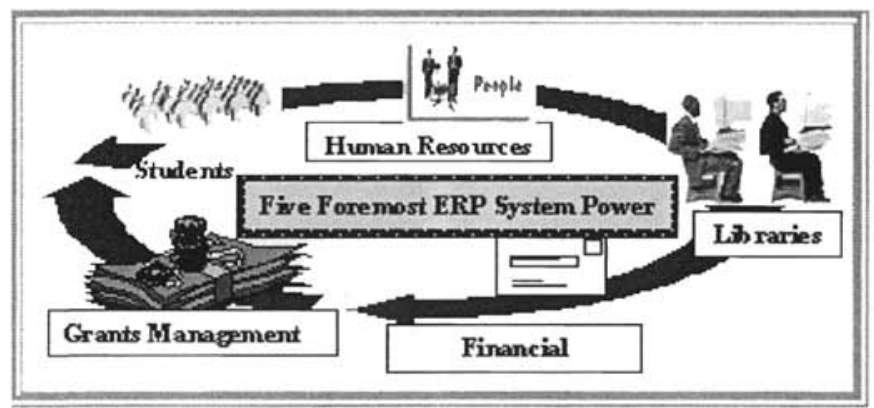

Figure 1. Core of ERP System in a University Situation

\section{ERP SYSTEM FROM UNDERNEATH TO PINNACLE}

ERP systems are "commercial software packages that enable the integration of transaction-oriented data and business processes throughout an organization"[2]. ERP make available the ideal solution - a sole integrated system for the central mapping, control and management of the data and procedure. It integrates company-wide data into a single system to make available a central point to deal with the business processes. ERP system integrates users, information, processes, and application for higher productivity [3]. It empowers management to make decisions based on complete, dependable, real-time information, improving their ability to take action in real time to changing business needs. ERP systems are the latest evolution of a technique of planning and controlling manufacturing businesses developed by the American Production and Inventory Control Society (APICS) in the early 1960's. The impression was initially termed material requirements planning (MRP) because of the technique's focus on material planning and procurement. The technique continued to be developed (in US consultancy, the Oliver Wight organization was predominantly noted in the field), and by the early 80 's, the term MRP-II came into use as the notion was extended to encompass high-level capacity planning. MRP became manufacturing resource planning and the 'II' was added to differentiate it from the preceding meaning. ERP is basically an updated term for MRP-II; initiate by software marketing in the mid-90's to modernize the thought. More or less any dialogue on enterprise resource planning (ERP) starts with material requirements planning (MRP-I) and MRP-II systems of the 1970s and 1980s. In the manufacturing environment of old, the artistic focus was on the competence to produce the product. This system 
integrates capacity, design engineering and management, costs, and long range planning of the enterprise into the equation. There are four stages to ERP. MRP: Material requirement planning, which was nothing but a historical background of ERP, the motive, was only to tap inventory i.e. raw materials planning. MRP-II: Manufacturing resource planning which look after production related things. The concept of MRP II was to look after shop floor and distribution management activities. ERP: Enterprise resource planning which role is very wider and not confined to one department but have a broader purview. ERP-II or MRP-III: Money resource planning or ERP-II advent can be seen few years after ERP system origination, which more emphasize on planning of capital or surplus money arises. An ERP system is an organizational and management solution based on information technology towards challenges and problems in the business [4]. ERP system has turn out to be a major force in enterprises use of information systems in recent years. ERP systems have several characteristics, such as a modular construction (contains a selection of application modules), which are based on a client/server architecture, allow configuration use a common (usually relational) central database, and have variable interfaces [5]. ERP system coordinates among people in, and between organizations and endow with procedures for accomplishing inter-personal change [6]. The ERP system even centralizes control, creates norms, and enhances power [7].

The ERP System is an information system designed to assimilate and optimize the business processes of an enterprise. Functions integrated by the ERP system include manufacturing, distribution, personnel, project management, payroll, and financials. Regardless of its high implementation and maintenance cost, the ERP System has become the de facto solution in industry to comprehend an enterprise-wide information system. According to a report by Advanced Manufacturing Research (AMR), the ERP software market is expected to reach $\$ 33$ billion by 2007 . The biggest challenge of teaching the fundamentals of the ERP systems in Universities is to teach it as a total since the essence of the ERP system is its integrative nature. ERP is not merely reengineering systems; it is reengineering the manner organizations accomplish business. In a recent CIO Magazine case study, Jeri Dunn, CIO for Nestle USA, said it this way, "If you weren't concerned with how the business ran, you could probably [install the ERP software] in 18 to 24 months" [8]. ERP is one of three enterprise-class applications, including Customer Relationship Management (CRM) and Supply Chain Management (SCM) that companies are deploying to automate business processes. ERP is focused on internal back office operation to external front office such as financial system, human resources, inventory management, shipping, customer order processing, warehouse etc [9]. ERP system style of functioning is very exceptional and bifurcated into four phases.

Step-1-Analysis: is a hardcore psychotherapy, which in a layman term known as pre-implementation stage. The user had to framework the mind to glimpse diverse alternative available and explore the dissimilar software package obtainable from the ERP vendor. This is also a stage when one should not think of outsourcing and creates an option to build-up own tailor-made in-house ERP packages. 


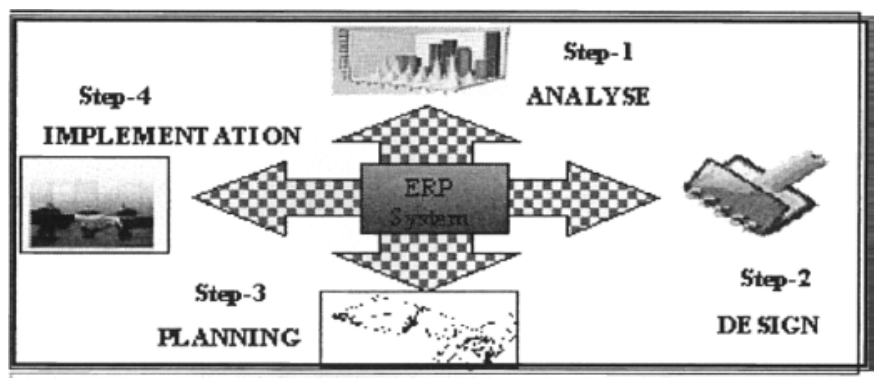

Figure 2. Steps to ERP System Style

Step-2-Design: Once the step one is performed the next job is to design the package according to the characteristics and job-profile of the enterprises. Let's take an example of Indira Gandhi National Open University in India-A pioneer \& No.-1 Mega University in the field of Distance Education and highest enrollment of students in the world, need packages, which can be acquainted in this existing environment. Like provision to share the study materials of the different schools \& discipline by one single student with the help of login name \& password. Here I would like to elongate with the help of example. There is a student of MCA who had been enrolled in the course known as Computer Basics from "School of Computer \& Information Science:" At hand School of Engineering \& Technology also have a similar course with different nomenclature but more or less the contents are much richer and elaborative. With the help of ERP system students had an option to go through this course and extract the necessary information. Thus proper designing of the packages can have a multiple possibilities to explore. The faculties of IGNOU deliver their thoughts ideas and course contents in the form of lecture through the EDUSAT (A Teaching through satellite which had been broadcasted through the Gyan Darshan Channel all over India). If the software is properly designed it will be hyper-linked through the IGNOU website and converted into MPEG format, which can easily be accessible from Media Players and effortlessly opened by the Students situated all over the world. Thus ERP System can make the purview bigger in a learning context.

Step-3-Planning: This exceptionally sensitive phase. History knows that wrong planning in the areas of software development had collapsed the existing as well as new system and put the organization on the deathbeds. One has to be very cautious in building the final shape.

Step-4-Implementation: This is joint effort done by the users and ERP vendors. The successful implementation require the amalgamation of all those who are associated it with it.

\section{ERP SYSTEM DISSIMILAR FROM LEGACY SYSTEM}

Enterprise spends an assortment of money on software systems and, to get hold of a return on that venture, the software must be functional for a number of years. The life span of software systems is extremely changeable but many large systems stay in use 
for more than 10 years. Some enterprises at a standstill rely on software systems that are more than 20 years old. Countless of these old systems are still business-critical. During the 1990s ERP systems were the de-facto standard for replacement of legacy systems in huge companies [10]. That is, the enterprise relies on the services endow with by the software and any breakdown of these services would have a severe repercussion on the routine running of the trade. These conventional systems have been given the name legacy systems. These legacy systems are not, of course, the systems that were primarily delivered. Exterior and interior factors, changing markets, shifting laws, management transformations and structural reorganization indicates that trade \& Industry undergo persistent revolutionizing. These changes generate newfangled or modified software requirements so all constructive software systems predictably change as the business changes. Accordingly the legacy systems insert a large number of changes, which have been made over many years. Innumerable divergent people have been involved in making these changes and it is astonishing for any one person to have an absolute understanding of the system. For the most part legacy systems encompass a number of dissimilar programs and shared data associated with these programs. This data may be detained in files or in an oldfashioned database management system. In the business systems domain, most legacy systems are furthermore batch-processing systems (Data is input and output in batches from a file relatively than input and output to a user terminal. Examples of batch processing systems are payroll systems, billing systems, etc.) Or Transaction processing systems (Data is input and output as a series of transactions alongside a database with the transaction generated from a user terminal). In both cases, the general organization can be represented using an input-process-output model. Legacy systems are not presently application software systems. They are socio-technical, computer-based systems so comprise business processes, application software, support software and system hardware. Nearly all legacy systems have been premeditated from a functional perspective and are composed of sets of interacting functions, which communicate all the way through parameters and global shared data areas. The business value of a legacy system and the quality of the application software and its environment should be assessed to help decide whether to replace, convert or maintain the system. The quality of the system depends on the excellence of the business processes, the quality of the application software itself and the quality of the hardware and software, which is used to support the system.

The Comparative Chart between the Legacy system \& ERP system shows that ERP systems are more contemporary as compared to the former one. The main USP of ERP system is that it had auto transaction features, which can facilitate the enterprise in integrating with multiple departments. The ERP System is the more dedicated packages (as compared to legacy system which are confined and restricted to particular applications) and are very versatile too. 


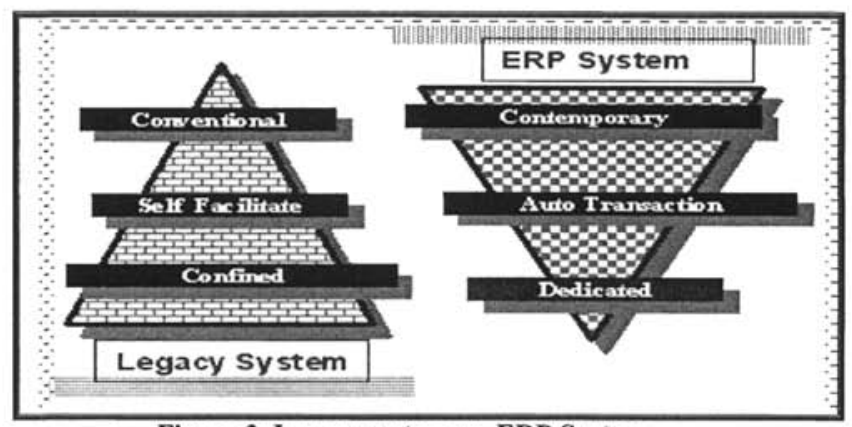

Figure 3. Legacy system vs. ERP System

\section{ERP SYSTEM IMPLEMENTATION IN A HIGHER EDUCATION}

Implementing an ERP system needs to be prospectively managed because of the far-reaching changes ERP brings to companies [11]. ERP is not merely reengineering systems; it is reengineering the manner organizations accomplish business. A burning aspiration about ERP system is making it as a fundamental motivation for higher education. That also has been ERP motivation for virtually past. By transforming raw data into genuine insight, software from ERP system yields knowledge. With historic strengths in data management, statistical analysis and cross-platform compatibility, ERP system facilitates member of the higher education community to accomplish new levels of knowledge. ERP world-class solutions ranges from web-enable to enterprise performance management and it permit students, faculty members, administrators and researchers alike to ascertain more from the data they accumulate. ERP taps the intelligence in enormous volumes of data and lets users pertain that knowledge to financial systems, enrollment management systems, human resources, information technology management and supplier relationship management. By merging industry expertise, proven methodologies and enabling technologies, ERP system brings exceptional solutions to higher education. Whether it means collecting and analyzing financial information for budget reports or understanding the collision of a new personnel policy, ERP system helps in strapping up the power of the data. Unlike other solutions on the market, ERP system works with existing systems and proficiently leverages the data. With the multi-vendor, multiengine architecture, ERP system taps data everywhere it exists - in legacy systems, spreadsheets or in new ERP systems. Thus, ERP system helps institutions formulate the virtually all of their existing investments, saving time and money. ERP system is fabricated on an open, secure and scalable framework that allows for rapid, end-to-end information delivery at the moment. And ERP system gives you the capability to Web-enable your data for even easier access or to present information visually, making it easier to comprehend. At foremost academic institutions, resources are too little and decisions carry longterm consequence. Accordingly, one wants the very best information on which to base 
decisions. ERP System solutions assist you in knotting together the supremacy of the data warehouse and other disparate sources, translating analysis into decisions and giving the institution a cutthroat frame. With key competencies in data mining, data warehousing, decision support, web-enable and information delivery, ERP System leverages these technologies to transport you solutions for: Enrollment management, financial management, Human capital management, Performance management, Supplier Relationship Management. Nowadays, ERP System meets the needs of decision-makers in higher education, with a promise to user-driven research, development and leading technology, etc. ERP System makes cutting-edge software voluntarily obtainable to colleges and universities, enabling them to construct data warehouses for easier access to knowledge (e.g., quality measures associated with graduate education such as cited publications, grants, scores, etc.). Engender reports, charts and graphs energetically for users via the web. Excavate data, uncovering new patterns and trends that minister in decision support (e.g., knowing which group of recruits is anticipated to sign up or which group of donors is most possible to make a payment to a capital campaign). Facilitate advanced analytics to sustain research. And finally make useful and easy-to-interpret reports from ERP systems, enabling the institution to leverage its full ERP investment.

\section{CHALLENGES IN IMPLEMENTING ERP IN AN UNIVERSITY'S ORGANISM}

As colleges and universities impart education, research and service, they struggle with manifold challenges. From well-ordered resource utilization to generating and maintaining well-built relationships, ERP system can facilitate on many levels. ERP systems make available cross-organization integration through embedded business processes and are generally composed of several modules including human resources, sales \& finance and, in the case of Universities, student administration [12]. Many universities have acknowledged the value of inserting ERP systems into university curriculum. ERP systems can be used to underpin many of the concepts covered in the business discipline [13]. Here are several of the numerous ways we convey:

Enrollment supervision: Upholding high-quality interaction with individual students is significantly vital to institutions of higher learning. This interaction can establish whether a forthcoming student enrolls; whether that student remains at the school to accommodate or transfers to another institution; and how openhanded he or she becomes as an alumnus. Now the million-dollar question is how do you take in strategy, process, culture and technology to optimize this relationship? Strategic Enrollment Management allows you to revolve data into information an institution can operate on. And ERP system presents it in a mode that perk up decision-making and communication via a user-friendly Web interface. 


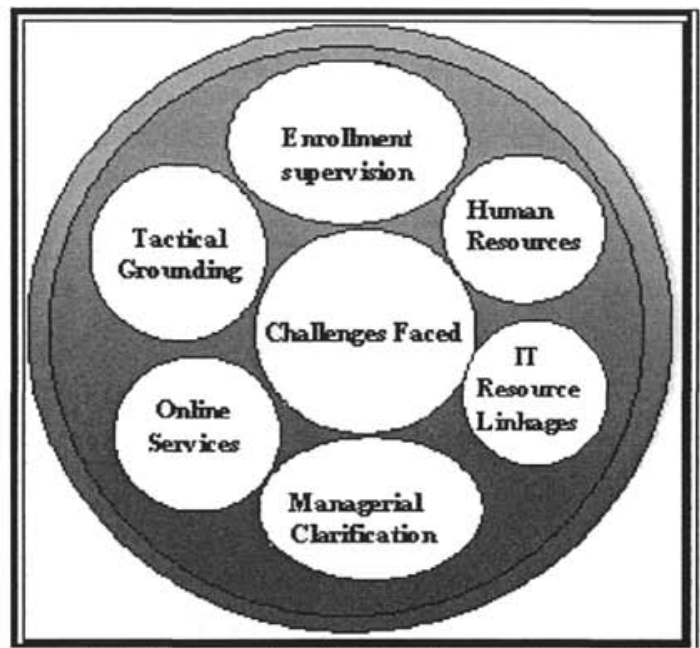

Figure 4. Challenges Faced In Implementing ERP System

Human resources: Education is a people-intensive enterprise. With limited resources, how do you maximize your human resource pool? What would help individual units plan and simultaneously provide the administration with reports they need? How can HR best support the institution's strategic goals? SAS-an ERP vendor which have a module entitled "Human Capital Management" gives you the world's only comprehensive decision support system for human resources. It specifically addresses the changing roles of HR professionals, linking people, strategy and performance to effectively track, measure and execute overall organizational goals.

IT Resource Linkages: It has to be articulated that scheduling for information technology is an oxymoron. Yet virtually each activity on and off campus uses IT. How do campuses best deal with a resource that is at all times in demand? How do you tie-up capacity management with security and optimization of resources, ensuring that users have access to technology 24/7? With the help of ERPs system the IT Resource administration is a comprehensive, enterprise wide approach to IT service reporting. It enables IT to "verbalize" to business by bring into line the IT path with the other institutional goals, while bridging organizational gaps

Managerial clarification: Many institutions that have made sizable investments in ERP systems are now seeking ways to get critical data from those systems and to capitalize on the ERP investment. By Employing ERP system, one can tie together the power of the ERP systems and influence the existing data for healthier decisionmaking.

Online services: Campuses have automated and re-engineered admissions and registration processes. Students have a preference to be online rather than in line. How does the institution incorporate its manifold interactions with students, generating a more interconnected, lifelong rapport? How can the institution intensify the relationship between an individual and his or her alma mater? ERPs System can work here as a Customer Relationship Management and gives the aptitude to distribute information and services from multiple sources, whether in person, over the 
phone or on the Web.

Tactical grounding: All academic state-of-affairs have a vision, mission and goals. But how well are those translated into actionable results all the way through the enterprise? Can the Vice-chancellor, Directors, provost or dean observe the impact of student services on the institution's long-term plan? How do individual units roadway their role to the institution's competitiveness? ERP's system tactical grounding Management translates stratagem into actions to be deliberate and monitored all through the enterprise. Data can be Web-enabled for trouble-free access by those who require it utmost.

\section{TECHNOLOGY (ERP SYSTEM) PROPOSED AT A UNIVERSITY SYSTEM}

The Proposed ERP System can, develop effective assessment methods for students' learning; Endow with the students with a challenging environment where they are vital to fabricate moderately a lot of professional skills such as an ability to function on culturally diversified teams and an ability to communicate effectively; Instruct engineering students the fundamentals of the ERP system through the construction of an executable ERP system; and Offer the students with the broad educational awareness of a global economy. Since a University is at the forefront of technology and are in the process to have some of the most hi-tech equipments it should be equipped with.

Endeavor to have a Wireless campus inside the campus and academic block.

All campuses suppose to be interconnected through a highly secured virtual private network.

The computers are connected to the Internet through broadband connections.

Wireless laptops provided to each faculties

Intranets automate most processes on campus first in the students support division to instigate admission system with complete online tracking.

Most advanced online counseling system facilitates quick response to queries training division to ensure that everyone at the University updated with latest technologies and trends.

Associated with Industry leaders for providing training on latest technologies

\section{SWOT Analysis}

The work of the SWOT Analysis is to Look the repercussion \& influences from all the way thus to retain the existing system and synergies it with ERP System. 


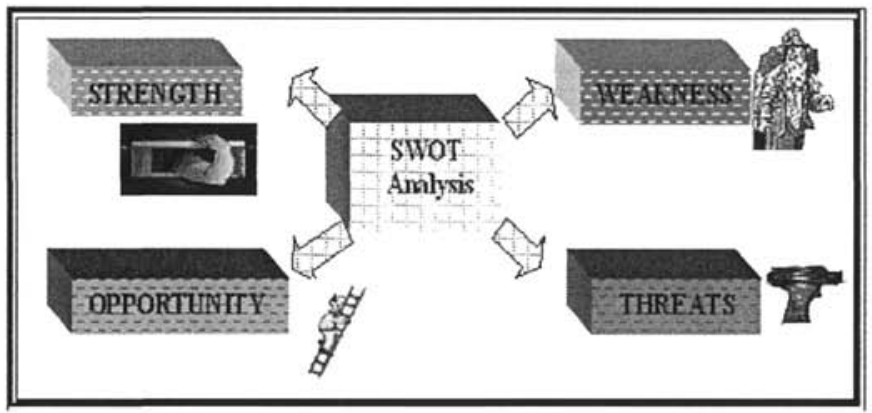

Figure 5. SWOT Analysis of ERP System

Table 1. SWOT Analysis of ERP System

\begin{tabular}{|c|c|c|c|}
\hline Strengths & Weakness & Opportunities & Threats \\
\hline $\begin{array}{l}\text {-ERP system } \\
\text { widens the well- } \\
\text { built will of the } \\
\text { university. } \\
\text {-Belonging to e- } \\
\text { campus is very } \\
\text { imperative for the } \\
\text { future development } \\
\text { of ERP System } \\
\text {-A system of } \\
\text { contact people in } \\
\text { faculties' active } \\
\text { mailing lists. }\end{array}$ & $\begin{array}{l}\text {-Teachers are } \\
\text { not in a position to } \\
\text { expand virtual } \\
\text { learning courses } \\
\text {-Need for } \\
\text { mechanical } \\
\text { competence in } \\
\text { preparing ERP } \\
\text { System-based } \\
\text { courses, } \\
\text {-Limited } \\
\text { funding for ICT- } \\
\text { based teaching } \\
\text { activities. }\end{array}$ & $\begin{array}{l}\text { Cannot invest } \\
\text { much funding and } \\
\text { personnel in the } \\
\text { projects, } \\
\text {-Use of ERP } \\
\text { system brings into } \\
\text { play a new form of } \\
\text { competition between } \\
\text { universities and the } \\
\text { private sector in the } \\
\text { education market } \\
\text { place. }\end{array}$ & $\begin{array}{l}\text { Humanizing } \\
\text { knowledge and } \\
\text { possibilities to } \\
\text { use the Internet, } \\
\text {-Developing } \\
\text { another way of } \\
\text { working }\end{array}$ \\
\hline
\end{tabular}

\section{CONCLUSIONS}

The biggest challenge of teaching the fundamentals of the ERP systems in Universities is to teach it as a whole since the essence of the ERP system is its integrative nature [14]. Institutions are looking for new tools, methodologies and solutions to multifaceted problems. Hundreds of companies declare to have solutions, but how do you know which would be most well organized for you? ERP's system provides a pilot methodology that allows institutions to expand an evidence of concept and refined project plan to be in no doubt that innovations are successful. At last the lesson learned is to, accomplish not get caught up in wishing for expensive technology or trying to design the perfect architecture, be acquainted with the gaps between preceding and post-ERP management data functionality, empathize those gaps with senior management, endeavor collectively and communicate, formulate the strategy consistent with current organizational structure, and at last not set expectations too elevated as this is a process that evolves over time. The important findings in implementing ERP System application such as SAP, BaaN, People Soft, and Oracle require teamwork from both the vendor and the institution. 


\section{REFERENCES}

1. S. Kesharwani, ERP Systems-New Fangled Approach to Manage Technology for competitive Advantage, Review of Professional Management. Volume 14, Number 1 , pp.52-58, (2006).

2. S. Axline, M.L. Markus, D. Petric, and C. Tanis, Learning From Adopters' Experiences with ERP: Problems Encountered and Success Achieved, Revised for Enterprise Systems: ERP Implementation and Effectiveness. eds. Shanks, Seddon and Willcocks (2001).

3. S. Kesharwani, ERP for Banking Industry, Management \& Change. Volume 9, Number 2, pp.109-115, (2005).

4. K.C. Laudon and J.P. Laudon, Management Information Systems - New Approaches to Organization \& Technology, 5th Ed (Prentice Hall: London, 1998).

5. T.H. Davenport, Mission Critical-Realizing the Promise of Enterprise Systems (Harvard Business School Press: Boston. 2000).

6. U. Melin, Coordination and Information Systems in Firms and Networks (Koordination och informations system in företag och nätverk) (In Swedish)), Linköping University, Sweden (2002).

7. G.M. Schwarz, Organizational hierarchy adaptation and information technology, Information and Organization-Elsevier Science. Volume 12, Number 3, pp.153-182, (2002).

8. B. Worthen, Nestlé's ERP Odyssey. CIO Magazine (2002). http://www.cio.com/archive/051502/nestle.html (Accessed August 20, 2006).

9. S. Kesharwani, ERP Systems- A critical factors for success, Review of Professional Management. Volume 3, Number 1, pp.78-90, (2005).

10. A. Parr and G. Shanks, A Taxonomy of ERP Implementation approaches, in The 33rd Hawaii International Conference on System Sciences (HICSS)(Maui, Hawaii, 2000b).

11. P. Bingi, M.K. Sharma, and J.K. Godla, Critical Issues affecting an ERP Implementation, Information Systems Management. Volume 16, Number 3, pp.7-14, 1999.

12. J. Esteves and J.Pastor, Enterprise Resource Planning Systems Research: An Annotated Bibliography, Communications of the Association for Information Systems. Volume 7, Number 8, pp.1-52, (2001).

13. I.B. Fernandez, K. Murphy, and S. Simon, Enterprise Resource Planning: Integrating ERP in the Business School Curriculum, Communications of the ACM. Volume 43, Number 4, pp.39-41, (2000).

14. Y.B. Moon and D. Phatak, Enhancing ERP system's functionality with discrete event simulation, Industrial Management \& Data Systems. Volume 105, Number 9, pp.1206-1224, (2005). 